\title{
Net gains
}

\section{アポロ計画とUNIX}

Nature Vol. 460(307)/16 July 2009

人類初の月面着陸はまさに世界を変えた。時を同じくして、世界を変える出来事がもう 1 つ起きていた。

40 年前、多くの若者はアポロ計画に大きな影響を受けて 科学者を志した。この事実は、多分野の研究者を対象とし て Nature が実施した国際的調査で明らかになった（2009 年 7 月 16 日号 314 ページ)。

1969 年夏、科学者はもちろん多くの人々が後に大きな 力を得ることになる別の出来事が、コンピューターの世界 で起こっていた。アポロ 11 号の飛行士が月面上に人類の 第一歩を記そうとしていた時、AT\&Tベル研究所の Ken Thompson は、新しい小型マシンの上に、もともとメイン フレーム (大型機) 用に作成したゲームプログラム Space Travel を移植する作業を進めていた。この研究がきっか けとなって、Thompson は後に Dennis Ritchie らと共同 でオペレーティングシステム（OS）を作成、UNIX と命 名する。そこから先は周知のとおり。UNIXは、今も続く 科学コンピューティングの引き金となり、オープンソース ソフトウェア運動の手本となり、UNIX から派生した数々 のプログラムとともにインターネットの基礎を築いた。

当初、UNIX は社内用だったが、1970 年代にベル研究 所が外部にライセンスするようになると、科学者の間に急 速に広がっていった。UNIXは、その能力、単純さ、それ に複数のユーザーとの情報交換を同時に実現できる点が支 持された。

UNIX の成功にとって、もう 1 つ重要だったのが時 代・タイミングだった。UNIX が登場したのは、ミニコン ピューターがメインフレームの座を脅かし始めた頃だっ た。UNIX はこの小型計算機用に簡単に改変できた。最も 重要だったのは、UNIXが C 言語で書かれていたことか
もしれない。この新しいプログラミング言語を使えば、プ ログラムの作成や共有などが簡単にできたので、研究者は 早速それに取りかかり、オープンソース運動の先駆けとな る数々のイノベーションが生み出された。

しかし 1980 年代から 1990 年代にかけて、このオープ ンな性格が商業権益の標的となり、互換性のない UNIX が 出回る事態になってしまった。そこを突いたのが新興企業 マイクロソフトで、急成長するマイクロコンピューター市 場で独自の OS を武器に支配的な地位を確立していった。

それでも UNIX の未来は、1970 年代後半には約束され ていた。米国防総省国防高等研究計画局（DARPA）が、 その多くのプロジェクトに使用する基礎ソフトに、当時、 カリフォルニア大学バークレー校で開発されていた UNIX のバージョンを選定したからだ。そして当時新しかった TCP/IP というインターネットの基盤をなすプロトコルを 実装させる研究資金を同大学に提供し、UNIX を基本的に インターネット対応にしてしまった。その後のインター ネットの展開において、オープンソース運動が中心的な 役割を果たすようになり、1991 年にフィンランドの学生 Linus Torvalds が作った UNIX のクローンである Linux が支配的役割を果たすようになった。今日、インターネッ トの基盤構成要素や大半の携帯電話や GPS 装置は、Linux などの UNIX 系 OS で運用されている。

トップダウンの巨大科学技術プロジェクトだったアポロ 計画とUNIX 開発。両者の間には決定的な差がある。し かし、ともに共同作業の力を示す実例とされ、後世に名を 残しているのだ。(菊川要 訳) 